\title{
Blood carbonyl protein measurement as a specific oxidative stress biomarker after intestinal reperfusion in rats $^{1}$
}

\author{
Dosagem da proteína carbonilada sanguínea como biomarcador específico do estresse \\ oxidativo após reperfusão intestinal em ratos
}

\author{
Márcio José JamelI, Lara de Paula Miranda Pereira", Natália Bernardes Mello"I, Elis Cristina Araújo Eleuthério"II, Alberto \\ Schanaider $^{\text {IV }}$

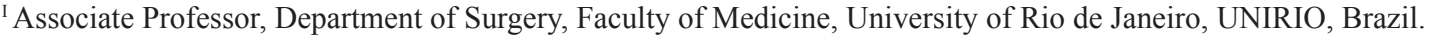 \\ ${ }^{\text {II }}$ Scientific Initiation Student, Faculty of Medicine, UFRJ, Rio de Janeiro, Brazil. \\ III Associate Professor, Department of Biochemistry, UFRJ, Rio de Janeiro, Brazil. \\ ${ }^{\text {IV }}$ Associate Professor, Head of the Experimental Surgical Center and Coordinator of Postgraduate Program in Surgical Sciences, UFRJ, Rio de Janeiro, \\ Brazil.
}

\begin{abstract}
Purpose: An experimental study was performed to investigate the use of protein carbonyl group as a specific biological marker for oxidative stress in a rat model of intestinal ischaemia-reperfusion. Methods: Twenty four male Wistar rats were randomly distributed into three groups with eight animals each: Group 1 - Control group; Group 2 - Sham; Group 3 - Intestinal ischaemia by clamping ileal branches of the superior mesenteric artery for one hour, followed by another hour of reperfusion. Blood samples were taken in order to analyze the protein carbonyl level by Slot blotting assay. Results: In group 3 a significant increase of protein carbonyl level was observed if compared to the homogenous levels of groups 1 and 2. Conclusion: From the results it may be concluded that the protein carbonylation may be used as a specific marker for measuring oxidative stress in rat intestinal reperfusion model.
\end{abstract}

Key words: Oxidative Stress. Free Radicals. Protein Carbonylation. Ischemia. Reperfusion. Intestine Small. Rats.

\section{RESUMO}

Objetivo: Realizou-se um estudo experimental com a finalidade de investigar o uso da proteína carbonilada como um marcador biológico específico do estresse oxidativo em um modelo de isquemia e reperfusão intestinal, em ratos. Métodos: Vinte e quarto ratos da linhagem Wistar, machos foram distribuídos, aleatoriamente, em três grupos compostos por oito animais cada: Grupo 1 - Controle; Grupo 2 - Simulação e Grupo 3 - Submetido à isquemia, mediante clampeamento de ramos ileais da artéria mesentérica superior por uma hora, seguida de reperfusão, por igual período. Amostras sanguíneas obtidas foram utilizadas para analise dos níveis de proteína carbonilada, através do método Slot blotting. Resultados: No grupo 3 houve uma elevação significante da concentração de proteína carbonilada sérica se comparada aos níveis sanguíneos homogêneos encontrados nos grupos 1 e 2. Conclusão: Fundamentado nos resultados é possível concluir que, a carbonilação protéica pode ser utilizada como um marcador específico para a mensuração do estresse oxidativo em modelos de reperfusão intestinal, em ratos.

Descritores: Estresse Oxidativo. Radicais Livres. Carbonilação Proteica. Isquemia. Reperfusão. Intestino Delgado. Ratos.

${ }^{1}$ Research performed at the Experimental Surgical Center and Post-Graduation Program, Department of Surgery, Faculty of Medicine, Federal University of Rio de Janeiro (UFRJ), Brazil.

\section{Introduction}

The correct diagnosis and treatment of vascular diseases of the bowel are still a challenge. The patient's symptoms are usually nonspecific and clinical or surgical approaches are based upon an understanding of the basic concepts of anatomy and physiology of the mesenteric circulation. Surgical management of intestinal ischaemia is usually limited to resection of necrotic segments and seldom to revascularization of a viable bowel. Unfortunately treatment of a misdiagnosed intestinal ischemia results in high morbidity or mortality indices.
In the last decade with the great development of molecular biology it has been shown that mesenteric obstruction followed by reperfusion or intestinal inflammatory disorders triggers a huge production of oxygen-derived free radicals with relevant deleterious effects on the intestinal wall ${ }^{1-4}$. These reactive species of oxygen involved as mediators of ischemia and reperfusion phenomena, oxidize proteins, lipids or DNA, and cause serious impairment of intestinal cell integrity, damaging their functions. The oxidative process brings about carbonyl groups in protein molecules which become markers, and can be detected in blood samples by using specific method as the Slot blotting assay ${ }^{5-8}$. 
A clearer understanding of the biochemical and morphological consequences of intestinal reperfusion is essential to achieve a better prognosis which may be improved by combining clinical and radiological exams with carbonyl protein measurement.

The objective of this study was to show the efficacy of the measurement of protein carbonyl group as a biomarker of intestinal reperfusion injury contributing to an early diagnosis and treatment in such circumstances.

\section{Methods}

The present study was carried out in the Experimental Surgery Center of the Faculty of Medicine of the Federal University of Rio de Janeiro (UFRJ), approved by the Ethical Committee for Laboratory Animals of the UFRJ and it was in accordance with the Guide for the Care and Use of Laboratory Animals (National Institutes of Health Publication, revised 1985).

Twenty-four male Wistar rats (Rattus norvegicus), weighing 200 to $250 \mathrm{~g}$, were fed with standard rat chow and submitted to fasting with water ad libitum for $24 \mathrm{~h}$ prior to the experiment. Xilasine $(3 \mathrm{mg} / \mathrm{Kg})$ and Ketamine $(25 \mathrm{mg} / \mathrm{Kg})$ were used for intramuscular anesthesia:

The rats were randomly divided into three groups with eight animals each. In group 1, Control group, just a blood sample was collected. In group 2, Sham group, it was performed a two hours long laparotomy. In the animals of group 3 after a midline laparotomy, four distal branches of the superior mesenteric artery were totally occluded by microvascular clamps for 60 minutes followed by equal period of reperfusion.

Intracardiac blood sample was collected from all animals under anesthesia and stored at $-80^{\circ} \mathrm{C}$.

Protein carbonyl group was evaluated by Slot blotting assay. First an aliquot of the plasma sample $(1 \mu 1)$ was slot-blotted onto a polyvinylidene difluoride (PVDF) membrane $(1 \mathrm{cmX} 1 \mathrm{~cm})$ using a Slot blot device. PVDF membrane was then incubated with $0.1 \mathrm{mg} / \mathrm{ml} \mathrm{DNPH}$ in $2 \mathrm{~N} \mathrm{HCL}$ for $5 \mathrm{~min}$, washed extensively in $2 \mathrm{~N}$ HCL (3-5 $\mathrm{min}$ ) and $100 \%$ of methanol (5-7 min) added to remove free unreacted DNPH. Then the membrane was treated with a primary anti-DNP antibody in concentration of $4 \mu \mathrm{l}$ for two hours, washed with PBS and finally treated with a peroxidase-conjugated secondary antibody. Slot blot detection was performed with chromogenic method. Image analysis of the plasma was carried out by using the Quantity One 4.5.0 1-D Analysis Software and the results were expressed as optical density (OD).

The Student $t$ test was applied to appraise the differences in the means or median values. Statistically significant differences between groups was admitted for $\mathrm{p}<0.05$.

\section{Results}

Data of each group expressed as mean, median and standard deviation of carbonyl protein levels of all animals showed a significant optical density increasing $(* p<0.05)$ in group 3 (Ischemia and Reperfusion) as compared to groups 1 and 2. There was no difference between Control and Sham group results (Table 1).

Results analyzed by statistic software for each group displayed a relevant increase of plasma carbonyl concentration in group 3 (Figure 1).
TABLE 1 - Individual results (optical density) of each group

\begin{tabular}{|c|c|c|c|}
\hline & Control & Sham & Ischemia/reperfusion \\
\hline & $n=8$ & $n=8$ & $n=8$ \\
\hline Median & 101,947 & 104,051 & 146,459 \\
\hline Mean & 102,127 & 103,755 & $147,797^{*}$ \\
\hline $\begin{array}{l}\text { Standard } \\
\text { deviation }\end{array}$ & 2,071 & 1,910 & 9,726 \\
\hline
\end{tabular}

$\mathrm{n}=$ size of the sample (eight rats each)

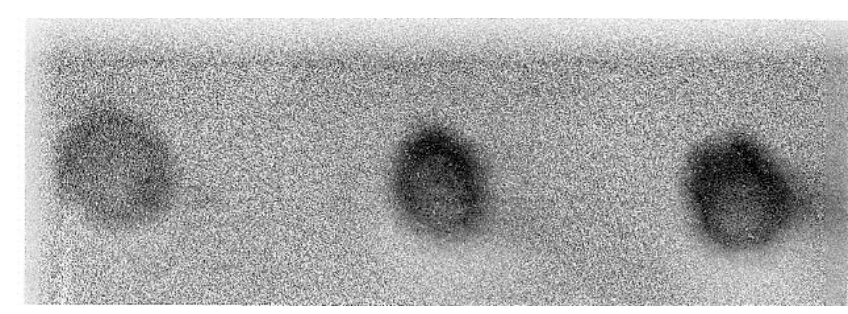

\section{G1 G2 G3}

FIGURE 1 - Scanned image of a polyvinylidene difluoride (PVDF) membranes recording the immunoblotting of carbonyl proteins presented in intestinal plasma samples in the three experimental groups. Group 1: Control; Group 2: Sham laparotomy; Group 3: Ischemia/reperfusion (I/R). The darkening of blots is correlated to the enhancement in carbonyl protein level in intestinal plasma samples

The variation of protein carbonyl content can also be seen in the Box-plots (Figure 2) which correspond to the images shown in Figure 1.

\section{Discussion}

Clinical diagnosis and treatment of intestinal ischemic syndromes are still a challenge. Most symptoms are usually nonspecific and even digital subtraction angiography, CT and MR imaging findings are not often helpful ${ }^{9}$.

Management of the bowel ischemic syndrome requires a continuing evaluation of all available data such as clinical signs, laboratory information and radiographic findings.

One of the main dilemma for the surgical team at the time of operation is to establish the limits of a viable bowel after a vascular impairment. Intraoperative parameters such as visual assessment of intestinal coloration, palpation of mesenteric pulses, peristalsis, bleeding of the intestinal surface after the resection, temperature and a sort of techniques to assure the intestinal viability are subjective and not conclusive in several occasions. Even senior surgeons are surprised with bad postoperative results although apparently the intestinal resection had been successful. Because of the difficulty in determining the intestinal viability during surgery, it is not uncommon to perform a second look operation in short period of time after the initial operation in order to evaluate a pos- 
sible resection of an extra intestinal segment that become ischemic or necrotic. This additional damage is not an unpredictable and solitary occurrence. Gastrointestinal surgeons must take into account the pathophysiologic mechanism by which oxygen-derived free radicals mediate injury during intestinal ischaemia followed by reperfusion ${ }^{10}$.

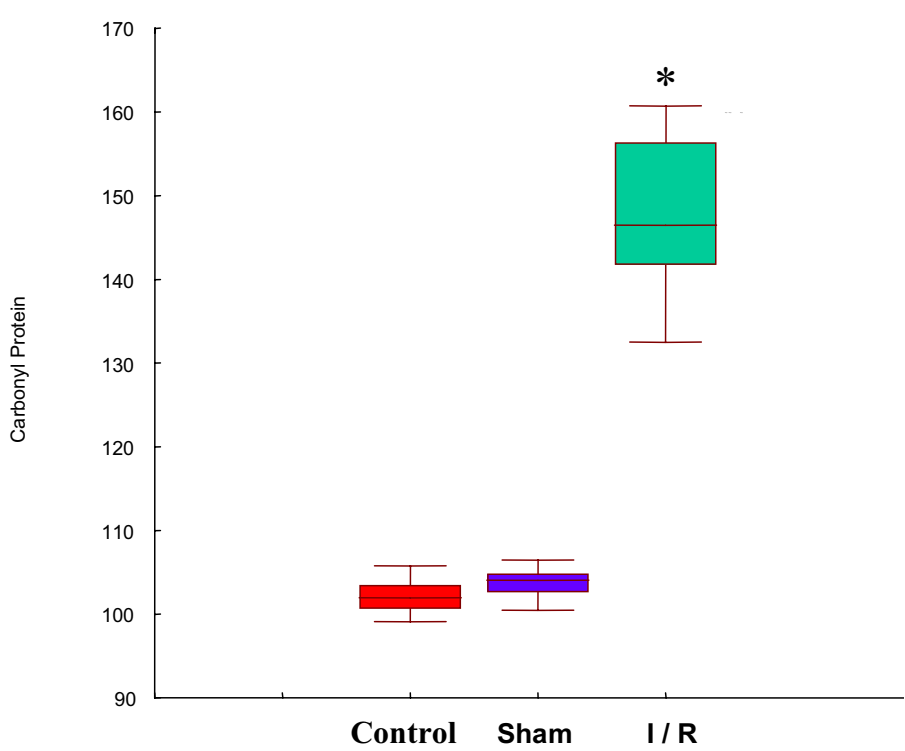

FIGURE 2 - The Box-plots show the variation of carbonyl protein content levels (optical density). The horizontal line in the box shows the results of median for groups Control, Sham and Ischemia/Reperfusion $(\mathrm{I} / \mathrm{R})$, respectively 101, 104 and 146 . Vertical lines in the box represent the maximum (max) and minimum (min) values. The boxes contain $25-75 \%$ of the experimental data. In group 1 (G1), Control, the $95 \%$ confidence interval for mean was 96.29 through 107.0 ( $\max =105$ and $\min =99)$ and the average absolute deviation from median was equal to 1.62. Group 2 (G2), Sham, had a $95 \%$ confidence interval for mean ranging from 97.94 through $108.6(\max =106$ and $\min =100)$ and the average absolute deviation from median was equal to 1.50 . The Ischemia/ Reperfusion group (G3) showed a significant increasing of carbonyl level with $\mathrm{p}<0.05(*)$ with $95 \%$ confidence interval for mean from 142.0 thru $152.7(\max =160$ and $\min =132)$. The average absolute deviation from median was 7.62

Nowadays, it is well known that the presence of the oxidative stress reaction is a sign of the existence of aggressions to homeostasis and organic systems ${ }^{10}$. The current study is not focused on intestinal necrosis. In such condition resection of the necrotic bowel is the goal of the treatment. An acute infarction of the intestine with irreversible lesions produces free oxygen radicals and oxidized proteins because of the development of an inflammatory process but it is reperfusion the main event capable to trigger a huge synthesis of free oxygen species in a burst reaction ${ }^{11}$. Revascularization of an ischemic bowel after a bypass graft, embolectomy, endarterectomy, reduction of an incarcerated hernia or surgical procedure to relief an intestinal adhesion with mechanical obstruction and ischaemia are examples of some etiologies related with oxidative stress. It must be emphasized that in such circumstances reperfusion injury is predictable and the best results are associated with preventive measures, including fluid therapy and perhaps radical scavengers administration to break up the free radical reaction chain.
In fact, those instable oxidizing species have cytotoxic effects virtually over all cellular components, not only disrupting membranes and cytoskeleton, but also compromising other important organelles such as lysosomes, mitochondrias and even nucleic acids.

The protein oxidative changes involving amino acid side chain give rise to a carbonyl group. Such modification could be detected in tissue samples ${ }^{4}$. An increasing number of studies on noninvasive measurements of protein carbonyl group in several human diseases have been published but few references are found concerning vascular diseases of the bowel ${ }^{11-14}$. Thus it seems useful to investigate if the blood measurement of protein carbonyl group could be used as a biological marker of oxidative stress of the intestinal tract.

The protein carbonyl is a molecule chemically stable and this characteristic is helpful for its detection and storage. Furthermore the protein carbonyl level in the plasma remains higher for at least 240 minutes and its increase takes place earlier than others products such as malondialdehyde from lipid peroxidation, a commonly used marker of oxidative stress ${ }^{15-18}$, that is likely to disappear in the first hour. The Slot blotting assay is easily performed; it needs a short period of time and low concentrations of proteins to accomplish the analysis of the oxidative process. We were able to measure a steady and significant increase of protein carbonyl group during the reperfusion period with high sensitivity and specificity by using the Slot blotting assay.

Measurement of protein carbonyl after major intestinal ischemia without reperfusion is not a very useful screening tool considering that most of the diagnosis is usually based on history and physical examination and treatment is limited to surgical approach with intestinal resection followed by clinical support. However when an ischaemic but viable bowel is present after a partial or intermittent vascular occlusion or in consequence of systemic causes (hypotension, hypovolemia, cardiac arrhythmias for instance) protein carbonyl evaluation should be helpful for the diagnosis. It is noteworthy that in that situation if the treatment of the intestinal vascular occlusion is postponed the antioxidant defense system will be overwhelmed by an exceeding rate of free oxygen radicals.

The ultra structural change after intestinal reperfusion and the presence of lipid peroxidation has been well established. Besides there is also growing evidence that supports the role of protein carbonyl in such conditions ${ }^{19-22}$. However, one major challenge still exists: how early intestinal reperfusion can be diagnosed before functional impairment or irreversible lesion comes true?

An early detection of protein carbonyl group could alert that an oxidative process has happened recently and help the physicians and surgeons to underline a better strategy in patients with suspected vascular disease of the bowel.

\section{Conclusion}

Our data suggest that protein carbonyl measurement in plasma is a useful tool as a biomarker of the oxidative stress in vascular disease of the small bowel, but further studies will be necessary to improve its applicability. 


\section{References}

1. Blikslager AT, Roberts MC, Rhoads M, Argenzio RA. Is reperfusion injury an important cause of mucosal damage after porcine intestinal ischemia? Surgery. 1997;121:526-34.

2. Thompson A, Hemphill D, Jeejeebhoy KN. Oxidative stress and antioxidants in intestinal disease. Dig Dis. 1998;16:152-8.

3. Abu-Zidan FM, Winterbourn C, Bonham M. Small bowel ischemiareperfusion increase plasma concentrations of oxidized in rats. Eur J Surg. 1999;165:383-9.

4. Schanaider A, Menezes VJMT, Borchardt AC, Oliveira PL, Madi K. Oxidized tissue proteins after intestinal reperfusion injury in rats. Acta Cir Bras. 2005;20:434-6.

5. Levine RL, Williams JA, Stadman ER, Shacter E. Carbonyl assay for determination of oxidatively modified proteins. Methods Enzymol. 1994;233:346-57.

6. Robinson CE. Determination of protein carbonyl groups by immunoblotting. Anal Biochem. 1999;266:48-57.

7. Levine RL. Carbonyl modified proteins in cellular regulation, aging and diseases. Free Radic Biol Med. 2002;32:790-96.

8. Buss H, Chan TP, Sluis KB, Domigan NM, Winterbourn CC. Protein carbonyl measurement by a sensitive Elisa method. Free Radic Biol Med. 1997;23:361-6.

9. Saba L, Mallarini G. Computed tomographic imaging findings of bowel ischemia. J Comput Assist Tomogr. 2008;32:329-40.

10. Paterno F, Longo WE. The etiology and pathogenesis of vascular disorders of the intestine. Radiol Clin North Am. 2008;46:877-85.

11. Dalle-Done I, Rossi R, Giustarini D, Gagliano N, Lusini L, Milzani A, Di Simplicio P, Colombo R. Actin carbonylation: from a simple marker of protein oxidation to relevant signs of severe functional impairment. Free Radic Biol Med. 2001;31:1075-83.

12. Berlett B, Stadtman ER. Protein oxidation in aging, disease, oxidative stress. J Biol Chem. 1997; 272:313-6.

13. Chevion M. Human studies related to protein oxidation: protein carbonyl content as a marker of damage. Free Radic Biol Med. 2000; 33:99-108.
14. Del Maestro RF. Ann approach to free radicals in medicine and biology. Acta Physol Scand Suppl. 1980;492:153-68.

15. Pantke U, Volk T, Schmutzler M, Kox WJ, Sitte N, Grune T. Oxidized proteins as a marker of oxidative stress during coronary heart surgery. Free Radic Biol Med. 1999;27:1080-6.

16. Erdogan H, Fadillioglu E, Yagmurca M, Uçar M, Irmak MK. Protein oxidation and lipid peroxidation after renal ischemia-reperfusion injury: protective effects of erdosteine and $\mathrm{N}$-acetylcysteine. Urol Res. 2006;34(1):41-6.

17. Del Rio D, Stewart AJ, Pellegrini N. A review of recent studies on malondialdehyde as toxic molecule and biological marker of oxidative stress. Nutr Metab Cardiovasc Dis. 2005;15:316-28.

18. Choi J, Malakowsky CA, Talent JM, Conrad CC, Gracy RW. Identification of oxidized plasma proteins in Alzheimer's disease. Biochem Biophys Res Commun. 2002;93:1566-70.

19. Dalle-Donne I, Rossi R, Giustarini D, Milzani A, Colombo R. Protein carbonyl groups as biomarkers of oxidative stress. Clin Chim Acta. 2003;329:23-38.

20. Schoenberg MH, Fredholms BB, Haglund U, Jung H, Sellin D, Younes M, Schildberg FW. Studies on the oxygen radical mechanism involved in the small intestinal reperfusion damage. Acta Physiol Scand. 1985;124:581-9. 21. Azevedo MAI, Azevedo LAI, Eleutherio ECA, Schanaider A. Propofol and $\mathrm{N}$-acetylcysteine attenuate oxidative stress induced by intestinal ischemia/reperfusion in rats: protein carbonyl detection by immunoblotting. Acta Cir Bras. 2008;23:425-8.

22. Rolim M, Eleutherio ECA, Colao CF, Cotta-Pereira G, Schanaider A. Colonic healing after portal ischemia and reperfusion: an experimental study with oxidative stress biomarkers. Redox Rep. 2007;12:267-74.

\section{Acknowledgments}

We thank the Fundaçao de Amparo à Pesquisa do Rio de Janeiro, FAPERJ, which granted a scholarship for scientific initiation student and support this research.

\section{Correspondence:}

Prof. Alberto Schanaider

Rua Eurico Cruz, 33/603

22461-200 Rio de Janeiro - RJ Brazil

alberto-sch@ig.com.br

Conflict of interest: none Financial source: FAPERJ

Received: August 21, 2009

Review: October 13, 2009

Accepted: November 10, 2009

\footnotetext{
How to cite this article

Jamel MJ, Pereira LPM, Mello NB, Eleuthério ECA, Schanaider A. Blood carbonyl protein measurement as a specific oxidative stress biomarker after intestinal reperfusion in rats. Acta Cir Bras. [serial on the Internet] 2010 Jan-Feb;25(1). Available from URL: http:// $\underline{\text { www.scielo.br/acb }}$
} 